Meta

Journal des traducteurs

Translators' Journal

\title{
Translation and the Circulation of Competing Narratives from the Wars in Chechnya: A Case Study from the 2004 Beslan Hostage Disaster
}

\section{Sue-Ann Harding}

Volume 56, numéro 1, mars 2011

URI : https://id.erudit.org/iderudit/1003509ar

DOI : https://doi.org/10.7202/1003509ar

Aller au sommaire du numéro

\section{Éditeur(s)}

Les Presses de l’Université de Montréal

\section{ISSN}

0026-0452 (imprimé)

1492-1421 (numérique)

\section{Découvrir la revue}

Citer cet article

Harding, S.-A. (2011). Translation and the Circulation of Competing Narratives from the Wars in Chechnya: A Case Study from the 2004 Beslan Hostage Disaster. Meta, 56(1), 42-62. https://doi.org/10.7202/1003509ar
Résumé de l'article

Le présent article analyse le reportage en russe et en anglais sur la prise d'otages qui frappa Beslan en Russie du Sud entre le $1^{\mathrm{er}}$ et le 3 septembre 2004, et se penche tout particulièrement sur les informations publiées en ligne au cours de la première journée de cette crise. Le corpus sélectionné et analysé provient de trois agences de presse distinctes : RIA-Novosti, une importante agence de presse russe contrôlée par l'État ; Kavkazcenter, le site web de la résistance armée tchétchène ; et Caucasian Knot, un site fondé par Memorial, l'organisation internationale et historique des droits de l'homme de Russie. L'étude a recours aux principes de la théorie narrative et allie les outils narratologiques d'analyse à la notion d'ontological narrativity' (Somers et Gibson 1994 : 38) et explore la construction des récits d'information publiés par chaque site web, avant de passer à une analyse comparée de leur traduction, publiée le jour même. Ce travail contribue donc au savoir académique sur la prise d'otages de Beslan et les discours générés par l'événement - en particulier ceux qui sont produits par des groupes marginaux et par le biais de la traduction - ainsi qu'au savoir sur le processus de construction narrative, alors même que les événements sont en train de se produire. L'article tire des premières conclusions quant à l'effet de la traduction sur ces récits rivaux, particulièrement ceux qui sont diffusés par des groupes contestataires et non dominants relativement au conflit politique violent, comme celui qui perdure en Tchétchénie et dans le Caucase du Nord.
Tous droits réservés @ Les Presses de l’Université de Montréal, 2011
Ce document est protégé par la loi sur le droit d'auteur. L’utilisation des services d'Érudit (y compris la reproduction) est assujettie à sa politique d'utilisation que vous pouvez consulter en ligne.

https://apropos.erudit.org/fr/usagers/politique-dutilisation/ 


\title{
Translation and the Circulation of Competing Narratives from the Wars in Chechnya: A Case Study from the 2004 Beslan Hostage Disaster
}

\author{
SUE-ANN HARDING \\ The University of Manchester, Manchester, United Kingdom \\ Sue-Ann.Harding@manchester.ac.uk
}

\section{RÉSUMÉ*:}

Le présent article analyse le reportage en russe et en anglais sur la prise d'otages qui frappa Beslan en Russie du Sud entre le 1 $^{\text {er }}$ et le 3 septembre 2004, et se penche tout particulièrement sur les informations publiées en ligne au cours de la première journée de cette crise. Le corpus sélectionné et analysé provient de trois agences de presse distinctes: RIA-Novosti, une importante agence de presse russe contrôlée par l'État; Kavkazcenter, le site web de la résistance armée tchétchène; et Caucasian Knot, un site fondé par Memorial, l'organisation internationale et historique des droits de l'homme de Russie. L'étude a recours aux principes de la théorie narrative et allie les outils narratologiques d'analyse à la notion d'ontological narrativity' (Somers et Gibson 1994: 38) et explore la construction des récits d'information publiés par chaque site web, avant de passer à une analyse comparée de leur traduction, publiée le jour même. Ce travail contribue donc au savoir académique sur la prise d'otages de Beslan et les discours générés par l'événement - en particulier ceux qui sont produits par des groupes marginaux et par le biais de la traduction - ainsi qu'au savoir sur le processus de construction narrative, alors même que les événements sont en train de se produire. L'article tire des premières conclusions quant à l'effet de la traduction sur ces récits rivaux, particulièrement ceux qui sont diffusés par des groupes contestataires et non dominants relativement au conflit politique violent, comme celui qui perdure en Tchétchénie et dans le Caucase du Nord.

\begin{abstract}
This paper examines Russian and English reportage published online over the course of Wednesday, 1 September, the first day of the three-day hostage-crisis that took place in Beslan, Southern Russia in 2004. The material selected for analysis comes from three disparate news agencies: RIA-Novosti, a major, state-controlled Russian news agency; Kavkazcenter, the website of the Chechen armed resistance; and Caucasian Knot, a site founded by Memorial, Russia's international and historical human rights society. Drawing on tenets of socio-narrative theory that combine narratological tools with the idea of 'ontological narrativity' (Somers and Gibson 1994: 38), the paper analyses the construction of the news narratives published by each website, before turning to a comparative analysis of the translated material also published that day. The paper thus contributes to academic knowledge regarding the Beslan hostage-taking and the discourses generated by the event - particularly those produced by fringe groups and in translation - as well as to knowledge of narrative construction as events are still occurring. Preliminary conclusions are drawn regarding the effect of translation on these competing narratives, particularly those circulated by opposition, non-mainstream groups concerning situations of violent political conflict, such as that which still continues in Chechnya and the North Caucasus.
\end{abstract}

\section{MOTS-CLÉS/KEYWORDS}

Beslan, Tchétchénie, Russie, théorie narrative, terrorisme, médias en ligne Beslan, Chechnya, Russia, narrative theory, terrorism, online media 


\section{Introduction}

Two questions provide the impetus for this paper. Firstly, given the extent of state control over Russian media, and the climate of impunity, intimidation and danger established in Russia under President Putin (1999-2008) and prevailing under President Medvedev, what other reporting on the Second Chechen War (1999- ) exists online? Secondly, given limited Western media coverage of the War, ${ }^{1}$ is this alternative reporting communicated to a wider audience of non-Russian speakers, and if so, how?

Numerous news and information websites report on, and from, Chechnya and the North Caucasus. ${ }^{2}$ Although they vary in emphasis and political opinion and are funded and operated by a range of organisations, all regard themselves as important sources of reportage independent from the Russian government and alternative to the mainstream press. ${ }^{3}$ For those that publish in more than one language, communication to a wider audience and hence, translation, is essential to their self-appointed mission to reach the "world" or "global (mirovoi) community," to "give to the international community the full picture of the tragedy occurring in Chechnya,"5 and to "add pressure on Western and Russian policymakers alike."6

To contribute towards the determination and description of the nature of this alternative reporting and its translation into English, this paper, in a case-study approach, examines Russian and English content of two well-established, representative fringe media websites - Kavkazcenter and Caucasian Knot - and compares it with commensurate content from RIA-Novosti, one of Russia's major, state-controlled news agencies. The content selected for analysis comes from all material posted by these three sites on Wednesday, 1 September 2004 that refers directly to the hostage crisis unfolding in School No.1 in Beslan, North Ossetia-Alania, Southern Russia.

That Wednesday was the first day of what turned out to be a three-day siege. With over a thousand people held hostage by an armed group of men and women, and more than three hundred killed by the time the siege came to an end, Beslan was Russia's worst hostage-crisis and, to date, there has not been another like it. Not an isolated incident, but one that is readily linked temporally and spatially to other acts of political violence (including several explosions and suicide-bombings in Russia and years of brutal military and guerrilla warfare in Chechnya and the North Caucasus), the hostage-taking attracted significant international attention, and precipitated changes in the strategies and policies of both the Russian government and the Chechen armed resistance. Although often referred to as 'Russia's 9/11' (Russell 2007; Hutchings 2009), in Russia, the attack in Beslan remains a marginalized, unresolved disaster, fraught with conflict, bitterness, anger and indifference (Phillips 2007; Politkovskaya 2007). ${ }^{7}$ For these reasons, along with the appallingly terrifying and ghastly details of the attack, the Beslan hostage disaster and the discourse surrounding it continue to demand our attention.

Scholarly discussion of the events of Beslan has so far focused largely on the socio-political repercussions of the attack and its aftermath, particularly with regard to hostage-taking, terrorism, counter-terrorism, and conflict between Russia and Chechnya (Blandy 2004; Plater-Zyberk 2004; Smith 2004; Stepanova 2004; Lynch 2005; Dunlop 2006; Dolnik 2007; Russell 2007; Dzutsev 2008). Media coverage of the Beslan siege has also been explored (Haraszti 2004; Russell 2007: 67-70; Politkovskaya 
2007: 155; Dzutsev 2008; Snetkov 2007), yet, with the exception of Hutchings' (2009) analysis of the main evening news programme on Russian television broadcast from 1-6 September 2004, all of these take a broad, post-attack perspective on the events in Beslan, none examine independent online media, nor do any of them consider the role of translation in the reporting of the events.

This paper begins to address this gap. It examines Russian and English reportage published online during the course of a single day, the first day of the attack, when details of what was happening, to whom, by whom, and why were very difficult to ascertain given the shock and confusion of local residents and the total capture and restricted isolation of the school and the hostages from the outside world. Thus, together with the larger study from which it stems, which analyses material published over the four consecutive days of the siege and its immediate aftermath (Harding 2009), this paper is a (case) study of news reporting constructed as events are still unfolding on the ground. Defining this news reportage as 'narrative' allows for a detailed textual analysis that not only contributes to scholarly knowledge of the events of Beslan and the discourse generated by them - including that generated by fringe groups and in translation - but to increased understanding of how narratives are constructed and ways in which they operate. The construction of narratives from events after they have occurred is arguably what much of history is about and has been dealt with extensively elsewhere, particularly in the work of Hayden White, for example. Studying the elaboration of narratives as they are being constructed offers a different vantage point (see also Ryan 1993).

The paper begins with a brief discussion of this theoretical framework and its assumptions. It then moves on to an analysis of the reportage published in Russian by each of the three websites, before turning to an analysis of the translated material. Although the analysis is limited, in that it is confined to reportage published on just the first day of the siege, some preliminary conclusions are drawn regarding the effect of translation on these competing narratives, particularly those circulated by oppositional and non-mainstream groups concerning situations of protracted violent political conflict, such as that which still continues in Chechnya and the North Caucasus.

\section{News as Narrative}

The material selected for analysis is defined in this study as narrative, that is, the configuration of events and elements into some sort of temporal (and often spatial) sequence. Thus, analyses can draw on the rich theoretical tools of traditionally textbased narratology, but also on the work of socio-communication theorists (e.g., Somers and Gibson 1994; Somers 1997; Bruner 1991; Fisher 1985, 1987/1989, 1997), who have come to adopt the ideas of "ontological narrativity" (Somers and Gibson 1994: 38). Ontological narrativity is understood to mean that narratives constitute rather than merely represent reality and are therefore "the primary form by which human experience is made meaningful" (Polkinghorne 1988: 1, see also Fisher 1987/1989; Carr 1986), are fundamentally linked to human agency (Taylor 1989; MacIntyre 1981; Somers and Gibson 1994; Whitebrook 2001; Baker 2006), and are used to account for, legitimise (and challenge) individual behaviour and the practices of institutions. 
Combining the two approaches into a socio-narrative theory allows for a narratological focus on the structures and operations of narratives, some of which are articulated in discrete texts, while understanding that such texts contribute, in turn, to our construction of narratives that are "diffuse, amorphous configurations...not fully traceable to any specific stretch of text but...constructed from a range of sources, including non-verbal material" (Baker 2006: 4). Sociological approaches that investigate ways in which narratives develop and operate in society can be constructive responses to what Mieke Bal has called "the major challenge posed to narratology: that of, precisely, the social embedding of narrative - in other words, its relationship to reality" (1985/1997: 181).

A layered definition of narrative is common in narratology, where various terms are used to distinguish between story and 'story told,' or narrative content and narrative form (Genette 1972/1980; Rimmon-Kenan 1983; Prince 1987/2003). Bal's “text, story and fabula" are useful for analysis, and are adopted in this study, although separating them out "does not mean that these layers 'exist' independently of one another" (1985/1997: 6). All we have before us are texts, language signs on screen and paper, and to look at the same thing as text, story, and fabula is simply to look more than once, each time "from a certain, specific angle" (1985/1997: 78).

A narrative text is "a text in which an agent relates ('tells') a story in a particular medium" (1985/1997: 5). This is the raw material, so to speak, posted on the three websites. Two narrative texts, one in Russian and the other in English, were extracted from each site, creating six narrative texts in all. A fabula, according to Bal, is "a series of logically and chronologically related events that are caused or experienced by actors" (1985/1997: 5), who in turn are "agents that perform actions," and together, "[e]vents, actors, time and location...constitute the material of a fabula [and are referred to] as elements" (1985/1997: 7 emphasis in original). Each of the six narrative texts relates the hostage-taking in Beslan, yet each one differs in the elements selectively appropriated and omitted. Furthermore, the story, or "way in which these events [or elements] are presented" (1985/1997: 6, emphasis in the original) is also very different. Elements can be attributed varying degrees of significance - Baker calls this 'weighting' (2006: 28) - amplified through the inclusion of greater details, allotted a greater proportion of the whole narrative through repetition and reiteration, interpreted "as crises of a particular magnitude or as turning points in the context of the overall narrative” (Baker 2006: 68), placed in various temporal or spatial sequences, and given very different characteristics. Narratives can also be, and commonly are, connected to other narratives. They are embedded in, framed by, or function as parts of, larger narratives already circulating with varying degrees of potency, thus altering the story as elements are reconfigured through the filter of these other narratives, ${ }^{8}$ and as others are 'filled in' when they appear, in light of the larger narrative, to be missing from an account. ${ }^{9}$

Another feature central to the analysis of narrative texts is the concept of the narrator, the agent that relates the story, for " $t]$ he identity of the narrator, the degree to which and the manner in which that identity is indicated in the text, and the choices that are implied lend the text its specific character" (Bal 1985/1997: 19). In this study, the narrator is understood to be the news agency that relates the story, yet, as $\mathrm{Bal}$ points out, the narrator does not relate continually, but "[w]henever direct speech occurs in the text, it is as if the narrator temporarily transfers this function 
to one of the actors" (1985/1997: 8). Identifying to whom the function of narrator is temporarily transferred and in what way, is one method of determining how the narrator lends the text its specific character. This paper seeks to investigate how the three narrators (and their temporary narrators) use fabula and story to construct a narrative text relating the events of the Beslan hostage-taking. What did they say, and how did they say it? Furthermore, each agency constructs not just one, but two narrative texts, temporarily transferring the role of narrator not to an actor, but to translators or other agencies. What, and how much, of each Russian narrative text, fabula and story can be found in its corresponding English narrative, and what, consequently, are the specific characteristics of the English narratives? These questions are considered in the analyses of the next sections. The Russian narratives of RIA-Novosti, Kavkazcenter and Caucasian Knot are first considered in turn before moving on to analysis of the three translated narratives.

\section{Russian Narratives}

After a brief introduction of each news agency, each of the following analyses begins with a qualitative and quantitative description of the narrative text, then discusses the temporary narrators (such as correspondents, eyewitnesses, officials, and other media) selected to contribute to the narrative, other narratives to which the Beslan narrative is connected, the inclusion of other texts (that is, texts relating, or referring to, events occurring prior to the attack), the characterisation of major actors and, finally, ways in which the three demands of the hostage-takers are presented. This structure is based on an intratextual model of analysis developed in my larger study (Harding 2009) that, after Bal (1985/1997), differentiates between narrative and nonnarrative material, and further differentiates the narrative material according to time and place. This model, or adaptations of it, could readily be applied to other comparable sets of data.

\subsection{RIA-Novosti}

The Moscow based Russian News \& Information Agency RIA-Novosti is a large, statecontrolled news agency, which, since its establishment in 1941 and through various incarnations since, has always been closely connected with the Soviet or Russian governments, with a client list that includes Russian presidential and government departments and ministries. Its website is published in ten languages and features news, commentaries, analyses, interviews, press conference transcripts, and image galleries. Articles and bulletins are posted every few minutes around the clock, generating large amounts of material every day. The agency is an example of a dominant, mainstream media outlet; not only is the site controlled by the state and supportive of government policy and action, it also has the resources to widely circulate its material.

On 1 September 2004, RIA-Novosti published over one hundred and twenty-four posts (just under 14,000 words) that mention the hostage-taking in Beslan. Repetition in the narrative text is common, with earlier posts amalgamated and re-posted as summaries, or repeated in their entirety with additional, updated information. While it is apparent that the agency has at least one correspondent at the scene, only six of the bulletins draw on reports from eyewitnesses, with the vast majority relying on 
statements from twenty-seven different local, regional and federal government officials for information. In fact, more than half of the day's posts (71) report not on the events taking place in, or near, the school in Beslan, but on the actions of government officials and personnel, such as the regional adoption of additional security measures, the preparation of medical supplies, rescue workers and psychological help, the cancellation of passenger flights and the setting up of a telephone 'hotline.' The temporary assumptions of the narrator's role by these officials pass without comment from RIA-Novosti, nor are the official actions ever questioned; they are reported as correct and appropriate, in a manner typical of the genre of mainstream news reporting, where "news is what an authoritative source tells a journalist" (Bell 1991: 191). Together they characterise the Russian government as resourceful and effective, and moving quickly and efficiently in proper response to the crisis.

In turn, more than half (38) of these posts report the comments and condemnations of the attack made by politicians, religious leaders and official spokespersons in the near and far abroad as news of the hostage-taking spread..$^{10}$ Almost all these statements include very specific references to the morning's attack, frequently calling for the immediate and unconditional release of the hostages and expressing abhorrence at the targeting of innocent children, desire for a peaceful resolution to the crisis and sympathy towards the Russian government and people. Some countries also condemn any, or all, forms of terrorism, others condemn international terrorism, and still others express solidarity with Russia in "the fight against international terrorism" (v bor'be s mezhdunarodnym terrorizmom) ${ }^{11}$ the phrase used by Russian politicians and media to refer to what has gained currency as 'the war on terror(ism). ${ }^{\text {'2 }}$ Thus, even when the identity of the hostage-takers was still unknown and their demands were reportedly concerning specific events in Ingushetia and Chechnya, RIA-Novosti repeatedly connected the particular, local narrative of the events in Beslan to a larger narrative of 'the war on terror(ism).' The effect of this is twofold. Firstly, it subsumes the details of the specific attack into an abstract and rhetorically powerful 'meta-narrative' of good versus evil, ${ }^{13}$ legitimising a simplistic, dualistic understanding of, and response to, what is a particular and complex situation. Secondly, it allows the Russian government to naturally assume the position of 'the good,' and enables it to claim overwhelming international support for its response to the crisis.

That Russia is a veteran in 'the war on terror(ism)' and still at the frontline is suggested by the inclusion in RIA-Novosti's narrative text of an account (spravka) summarizing Russia's three largest hostage-takings, events in 1995, 1996 and 2002 when large numbers of people (between eight hundred and two thousand) were taken hostage by Chechen guerrilla fighters resulting in the deaths and injuries of scores of civilians. Furthermore, in an article filed from Moscow describing the candles and flowers laid at the Rizhskaya Moscow metro station, RIA-Novosti positions the attack in Beslan as the latest in a series of tragic events suffered by Russia. ${ }^{14}$ Russia knows about terrorism, suggests the narrator through these narrative connections; we are not new to the experience and our resourceful, good government knows how to fight our enemies.

Who are these enemies? By far the most frequent word used by RIA-Novosti to describe the hostage-takers is boeviki, ${ }^{15}$ followed closely by terroristy (terrorists) and bandity (bandits), ${ }^{16}$ all of which are used consistently by Russian politicians and 
media to refer to separatist and rebel fighters in the Caucasus, particularly in Chechnya. The group is reported to include two terroristki-smertnitsy ([female] terrorist suicide-bombers), ${ }^{17}$ or shakhidki, a Russianized feminine form of the Arabic shahid (or shaheed) coined after the Dubrovka theatre complex in Moscow was seized by Chechen terrorists in October 2002 and meaning a female suicide bomber. ${ }^{18}$ Thus, already on the first day of the siege, the RIA-Novosti story characterizes the hostage-takers as Chechen, even though, so far, the only reported information regarding their identity is the suggestion that the group is led by an Ingush known as 'Magas,' the same man who allegedly led an armed attack on Ingushetia on the night of June 21. ${ }^{19}$ This Chechen characterisation is reinforced by RIA-Novosti's inclusion of a report taken up in the US media claiming that one of the hostage-takers, who spoke "in Russian with a strong Chechen accent," telephoned the New York Times and said the group of hostage-takers was from "Riiad as-Salikhiin," a banned international terrorist organization that, "according to information from the media," was created, and is controlled by, "Chechen terrorist," Shamil Basaev.

What do the hostage-takers want? At first, nobody knows, but as various attempts at communication are reportedly made throughout the day, three clear demands gradually emerge. The first is the group's demand to meet with the presidents of North Ossetia and Ingushetia, Aleksandr Dzasokhov and Mura Ziazikov, and with Dr Leonid Roshal. While little is said of the two presidents, much is made of Dr Roshal. The narrator follows his movements throughout the day, reporting an interview with him in Moscow as he prepares for departure, his flight to Beslan, and finally his arrival and presence in operational headquarters. He is described as "the well-known paediatrician" who,

in October 2002 took part in the release of the hostages seized by fighters in the building of the Dubrovka theatre centre. The doctor conducted negotiations with the terrorists about the release of children, and about the relaying of food, water and medicines to the hostages.

The second demand of the hostage-takers is reported as "the release from prison of all those convicted of terrorism," a phrase used four times before eventually clarified in a quotation from Russian presidential advisor, Aslambek Aslakhanov, where it turns out to refer to "those who took part in the seizure of buildings of the security forces in Ingushetia on 21 June." It is in the same quotation that the third demand is reported for the first and only time, namely "the cessation of military activity in Chechnya and the withdrawal of troops from the republic."

The varying significance placed on these three demands by the narrator is evident not only in the characterisation of the actors - Dr Roshal as an experienced, successful negotiator, and the prisoners as 'terrorists' - but in the varied repetition and sequential ordering of the demands themselves. The first demand is repeated ten times in the narrative, the second demand five times and the third only once, when, late in the day, it is included almost inadvertently in Aslakhanov's quote. Thus, the demand to meet with the presidents and presidential advisor is accorded the greatest significance, and Roshal's quick response to the demand reinforces RIA-Novosti's characterisation of the Russian government as responding quickly and appropriately to the crisis. At the same time, attention is deflected away from regional conflict (dismissed as 'terrorism'), and the presence and military action of Russian troops in Chechnya is all but ignored. 
RIA-Novosti's close association with the state is clearly manifested in its Russian narrative, the longest (in words) of all six texts analysed in this paper. Official sources from local, regional, federal, and international authorities make up the overwhelming majority of the sites' temporary narrators and, through their sheer numbers and the repetition of their statements, they are instrumental in the construction of this narrative. Thus, the Beslan narrative is repeatedly framed by the narrative of 'the war on terror(ism)' and the Russian state is consistently characterised as the default force for good in this narrative, an experienced veteran in this war, capable of quickly and effectively mobilising resources and personnel (such as the able Dr Roshal) for the rescue of its citizens from the Chechen boeviki/terroristy/suicide-bombers and their illogical, obscure, impossible demands.

\subsection{Kavkazcenter}

Kavkazcenter describes itself as a Chechen, independent, international, Islamic, Internet news agency, established to cover events in the Islamic world, the Caucasus and Russia, with special emphasis on events in the Chechen Republic of Ichkeria "concerning Russia's military aggression." ${ }^{20}$ Publishing in Russian, English, Turkish, Ukrainian, and Arabic, it aims to disseminate its views and information under conditions of what it calls a "total informational embargo." While the site claims not to reflect the views of any state or government, it openly presents the position of the "Chechen mujahedeen," and, up until the unilateral declaration of the Caucasus Emirate in 2007 that effectively split the Chechen Resistance into two factions, had strong links to the Chechen-Ichkerian government-in-exile. Hosted in Finland after several attempts by the Russian Federal Security Service (FSB) to shut it down, Kavkazcenter has for many years been considered "the major Internet site of the Chechen Resistance." ${ }^{21}$ It is used in this study as an example of a non-state movement vying for legitimacy, players that are frequently overlooked in Western academic criticism of government and dominant discourses (Bhatia 2005).

On 1 September 2004, Kavkazcenter published twenty-seven posts (almost 2,500 words) that refer to the hostage-taking in Beslan. Like RIA-Novosti, most of these are brief bulletins, but in contrast, these are not repeated and there are no summaries. The narrative is assembled from elements drawn neither from the agency's own correspondents nor from the statements of officials, as is the case with RIA-Novosti, but, for the most part, from a variety of Russian print and electronic media. The site is often critical of the information, and a strong sense of the narrator's presence is provided by frequent comments and additions such as adding the word allegedly (iakoby) to statements, highlighting conflicting reports, pointing out the lack of evidence to support statements given by Russian authorities, and even accusing Russian sources of concealing information and editing television footage.

The statements and actions of politicians and officials that so characterised the RIA-Novosti narrative are all but absent from the Kavkazcenter narrative, with the focus of the narrator remaining almost exclusively on events taking place in Beslan. Officials are quoted, but with the site's critical tone of scrutiny and scepticism, unlike RIA-Novosti, which reports without comment. News for Kavkazcenter is not what an authoritative source tells a journalist, but what the narrator has to say about official statements and their sources. The narrative text also includes official statements 
which are absent from RIA-Novosti. Russian State Duma deputy, Mikhail Markelov, who is present at the scene, tells Interfax that the terrorists are following the news, that they are "literally standing in front of the televisions," but the observation goes unmentioned by RIA-Novosti. A statement made late in the evening to the relatives of the hostages by Stanislav Kesaev, deputy chair of the North Ossetian parliament, and Soslan Sikoev, the republic's deputy minister of Internal Affairs, that no contact had been made with the terrorists, also goes unreported by RIA-Novosti, possibly because, by this time, command had been handed over to the FSB, who had already claimed that contact had been made and negotiations were continuing. Akhmed Zakaev, representative of the Chechen government-in-exile, states that President Maskhadov and the Chechen-Ichkerian official structures have nothing to do with the Beslan attack, but, as both are considered terrorists by the Russian government, it is no surprise that his statement goes unpublished by RIA-Novosti.

Kavkazcenter includes none of the international and Russian responses to the siege that make up such a large proportion of the RIA-Novosti narrative and that create such a clear connection between the Beslan attack and 'the international war on terror(ism).' A single official statement, however, from Umar Khanbiev, general representative abroad of the Chechen-Ichkerian president, constructs an alternative connection. Like others, Khanbiev condemns both the explosions in Moscow and the taking of schoolchildren hostage in Beslan, but he goes on to connect these events not to a war on terror but to a narrative of violent conflict in Chechnya and the suffering of the Chechen people as targets of Russian military aggression:

There is no justification for this inhuman act, just as there is no justification for the murder of 42,000 Chechen schoolchildren by Russian militarists acting on the order of the Kremlin regime and Putin himself. The genocidal war against the people of the Chechen Republic Ichkeria and the criminal-terrorist policies of the Kremlin regime are the detonator destabilising the whole of the Caucasus and Russia itself.

Khanbiev condemns and does not condone the terrorist attack, but insists that "Russia's countless crimes against humanity on Caucasian soil make possible retaliatory, desperate, and brutal steps like today's act" and that a "policy of terror against the people of the Caucasus" can only bring about a "situation that is out of control and has unforeseen consequences."

This characterisation of the Russian government is very different from that of the resourceful and effective state found in the RIA-Novosti narrative. Indeed, the only Russian government action reported by Kavkazcenter is Moscow's appeal to the United Nations Security Council for an urgent extraneous session. Here the agency also connects the Beslan narrative with the narrative of the wars in Chechnya, remarking rather bitterly that the UN have never before acted so promptly with regard to Chechnya.

This narrative of Russian aggression and Chechen suffering is completely absent from the RIA-Novosti narrative; there is no reference to it at all in any of the international or Russian official responses. Links to the situation in Chechnya are made by RIA-Novosti, through Russian rather than foreign officials, but these are to the presidential elections held in the republic the previous Sunday. Russian Foreign Minister, Sergei Lavrov, for example, tautologically remarks that the attacks "confirm the fact that the process of stabilisation in Chechnya is not to the liking of those who want to wreck the process of peace and stabilisation in the Chechen republic." 
Another element unique to Kavkazcenter's narrative text is an impassioned plea addressed to President Putin from survivors of the 2002 Dubrovka theatre siege in Moscow. Recalling the 'brilliant' («blestiashchaia») operation to free the hostages that orphaned ninety-six children, killed 130 people and left survivors still today in need of hospitalization, the survivors now beg Putin to "spare the children!" (poshchadite detei!)

You, Vladimir Vladimirovitch, as the Guarantor of our right to life, are OBLIGED to do everything possible and impossible through peaceful negotiations. Do not conduct one of your new 'brilliant' storms to release the hostages and do not force us all to live again among the tombstones of our children! (emphasis in original)

Thus, in a reflection of "the paradox of the threefold present" (Ricœur 1979: 18) which, after Augustine, includes a present of things past (memory), a present of things present (attention) and a present of things to come (expectation), Kavkazcenter's narrative of events unfolding in Beslan connects to a past narrative in a way that anticipates the future. The Dubrovka theatre attack is not recalled as an example of terrorism in Russia, against which the Russian government is effectively mobilized, but as an ominous example of what may yet happen in Beslan. This anticipation, highlighted by the inclusion of the survivors' plea, acts as a plot, determining the selection of elements while, at the same time, achieving its form and nature only because of its particular constituent parts (Bruner 1991). Kavkazcenter includes elements that refer to the threat of an assault on the school, and their inclusion effectively evokes the threat of an assault. The site reports, for example, that "the relatives of the hostages are not alarmed so much by the seizure [of the school] as by the possibility of a storm by the Russian security forces." The hostage-takers themselves seem aware of this plot, reportedly threatening to blow up the school if it is stormed and "allegedly" placing children in the school windows to prevent an assault. ${ }^{22}$ The dualistic 'good' versus 'evil' found in the RIA-Novosti narrative is undermined here and the Russian government and security forces are not as 'good' as they would like to seem.

Similarly, Kavkazcenter pointedly avoids all the words used by RIA-Novosti to refer to the hostage-takers, instead using arguably more neutral terms such as vooruzhennyi otriad (armed detachment), vooruzhennaia gruppa (armed group), vooruzhennye liudi (armed people) or, on one occasion, napadavshie (attackers). Of the women, nothing is said except that there are women in the group. Official claims regarding the identity of the hostage-takers are met by Kavkazcenter with criticism and scepticism. The supposition put forward by "the Russian authorities" that the hostage-taking was carried out by members (boitsy) of the "Ingush Jamaat," and organized by Chechen Ichkerian leaders Aslan Maskhadov, Doku Umarov, and Shamil Basaev is immediately dismissed by pointing out that the Russians have produced no facts to support it, and by reporting Akhmed Zakaev's disclaimer. As for the New York Times' story reported by RIA-Novosti, Kavkazcenter points out that, so far, there has been no statement from "Riiadus Salikh'iin" even though their usual practice is to claim their involvement in any military or sabotage actions. The site also wonders how an American journalist might recognize a Chechen accent.

The three demands of the hostage-takers that emerge in the RIA-Novosti narrative are also reported by Kavkazcenter, yet with significant differences. Less emphasis is placed on the first demand to meet with the presidents of Ingushetia and North 
Ossetia and Dr Roshal, and no hope at all is placed in the character of Dr Roshal, who, in place of RIA-Novosti's accolades, is described simply as "a participant in the negotiations at Nord-Ost." Rather than tracking his movements throughout the day, Kavkazcenter reports only the statement from Valerii Andreev, head of the FSB in North Ossetia, that "measures are being taken to search for Doctor Leonid Roshal in order to bring him to Beslan and continue the negotiating process," at which point Kavkazcenter remarks drily that, "It is not quite clear why the FSB is stating that it is looking for Doctor Roshal when it is well known that Roshal is on the staff of the FSB."

The second demand of the hostage-takers is "the release of all hostages locked up in prisons in Ingushetia... after a mujahideen raid.' Like the polysemous boeviki, mujahideen (modzhakhed) has become an indeterminate term in Russian, yet given Kavkazcenter's support for them in its own mission statement, characterising the events in Ingushetia as a 'mujahideen raid' rather than the 'terrorist attack' found in RIA-Novosti's story is a clear indication of Kavkazcenter's support for, and legitimization of, the action. Kavkazcenter also reports the demand as "the release from prisons and Russian concentration camps of those held hostage in Ingushetia," deflecting the violence of the hostage-takers in Beslan and on to the federal and regional authorities, who are characterised as running concentration-camps and holding their own hostages.

The third demand, mentioned almost in passing by RIA-Novosti, is reported three times by Kavkazcenter, indicating the importance the site places on it. Apparently conveyed in a note thrown out of a window of the school, ${ }^{23}$ Kavkazcenter expresses this third demand as "the withdrawal of Russian occupation troops from Chechnya," again recasting the Russian government as aggressor. The depreciation of this demand by the Russian authorities is also noted, with Kavkazcenter reporting that the Russian authorities are refuting it, claiming no demands have been made, and concealing and editing out information regarding any demands.

Using a selection of other media, alternative official statements, and its own highly critical and sceptical narrative voice, Kavkazcenter constructs a narrative of Beslan that contrasts starkly with that constructed by RIA-Novosti. It connects the attack not to any 'war on terror(ism)' but to Russia's "genocidal war against the people" of Chechnya and to the disastrous outcome of Russian special forces' intervention at the Dubrovka theatre siege in 2002. Thus, far from a well-mobilized, benevolent state, Kavkazcenter characterises the Russian government as dangerous, untrustworthy, and not adverse to using its destructive physical power against innocent children and civilians. The site also deflects accusations of violence away from the hostage-takers, referring to them in relatively neutral terms and insisting that their identities are, at this stage, completely unknown. Yet their demands - the release of hostages captured after a legitimate raid and the end of war in Chechnya through the withdrawal of Russian troops - are entirely clear and comprehensible; even just.

\subsection{Caucasian Knot}

Caucasian Knot, established in August 2001, was founded by Memorial, the international historical and human rights society set up during perestroika, nominated for the Nobel Peace Prize in 2007, and winner of the European Parliament's Sakharov 
Prize for Freedom of Thought in 2009. The website publishes in Russian and English, posting news, analyses, documents, and information on the Caucasus and Southern Russia with particular focus on civil society and human rights, and with the stated aim of providing "free access to truthful and unbiased information....and information support for the development of civil initiatives and independent media." 24

On Wednesday, September 1 2004, Caucasian Knot published thirteen articles (just over 3,000 words) that mention the hostage-taking in Beslan, creating a narrative text that features characteristics of both RIA-Novosti and Kavkazcenter. There is some repetition, but typically only an occasional sentence rather than whole bulletins as in the case of RIA-Novosti, and, as with Kavkazcenter, there are no summaries. For all but one of the bulletins, the source (istochnik) is given as "our own information" (sobstvennaia informatsiia), even though at this stage it is unclear whether the site has a correspondent at the scene. Like RIA-Novosti, the narrator draws on information from official sources, but it appears to have a much more regional (NorthOssetian) focus, and includes, like Kavkazcenter, statements from Chechen-Ichkerian government officials as well as from sources found in neither of the other narratives, such as North Ossetian mufti Ruslan Valgasov and Beslan City Hospital's chief doctor. Like Kavkazcenter, but far less frequently and without the critical tone, the agency also cites other Russian media and draws attention to conflicting information between media reports and official statements.

Like RIA-Novosti, Caucasian Knot covers not only events in Beslan, but official actions across the region and in Moscow, with particular focus on regional activities such as the cancellation of school assemblies, the preparation of medical aid, the closure of Beslan airport, roads and borders, increased security, and the mobilisation of troops and special forces. While President Putin's return to Moscow, his high-level meeting, and his phone call with the North Ossetian president are also reported, the effect here is less of a mobilised state responding to a crisis, and more of a source of information for local residents regarding the practical and immediate effects of the state's action on their daily lives.

Of the numerous condemnations and condolences from abroad reported by RIANovosti, Caucasian Knot reports only the first four: statements from the Parliamentary Assembly Council of Europe (PACE), the European Parliament, Poland and Georgia. These are reported in a single bulletin, which is, in fact, patched together almost word for word from four RIA-Novosti posts. Together, the statements condemn the attacks in Beslan and Moscow, with Poland and Georgia condemning all, or any, forms of terrorism, and Europe offering solidarity and assistance. There is no further elaboration. Neither 'the war on terror(ism)' narrative, nor the larger narratives of the wars in Chechnya and the storming of the Dubrovka theatre are found here, almost as if, still in the process of assembling this particular unfinished narrative, the narrator finds itself in no position to yet make connections with other narratives.

Uniquely, Caucasian Knot includes two personal stories of people involved in the siege. The first of these to act as a temporary narrator for the agency is Soslan Fraev, whose brother, Ruslan, is one of two policemen killed during the capture of the school. Fraev, who is given a brief narrative of his own - he is a free-wrestling European champion and Asian Games prize-winner, so probably something of a local celebrity - relates how his brother drove his children to school that morning and, when he realised the school was being attacked, jumped out of the car and ran up to 
the school where he was killed. Ruslan's body lies in the school yard, unable to be reached because of firing, information included in both the RIA-Novosti and Kavkazcenter narratives, but only Caucasian Knot reports the personal narrative of how Ruslan, father and brother as well as policeman, was killed. The story is brief, no more than a few lines, but is told as an integral part of the news; in the same bulletin, Caucasian Knot officials talk of numbers: "seven people dead," "eleven wounded," "a seventy-one-year-old man seriously injured," while the narrative is of a person, "a life that qualifies for recognition" (Butler 2004: 34).

The second personal narrative is that of a local policeman, who is captured, and his vehicle commandeered, by the hostage-takers on their way to Beslan. "Somehow able to escape" after the attack, his story adds details to the Beslan narrative - the number of hostage-takers, the two dogs with them, and from which direction they came - all of which are missing from RIA-Novosti and Kavkazcenter. Although such small details may seem insignificant at first, particularly when overshadowed by elaborations of 'the war on terror(ism)' or war in Chechnya, they become less so when official narratives of the hostage-taking are later reconsidered, and questions asked about how the hostage-takers and their weapons could have moved so freely into Beslan and its School No.1. ${ }^{25}$

Unlike RIA-Novosti, which quickly characterises the hostage-takers as Chechen and 'international' terrorists, Caucasian Knot, like Kavkazcenter, remains circumspect. It refers to the hostage-takers almost exclusively as boeviki and terroristy, and describes the women as wearing suicide bomber belts (snabzhennye poiasamu smertnikov). It reports both the suggestion (found in RIA-Novosti) that the group is led by the Ingush 'Magas,' and the claim (reported and dismissed by Kavkazcenter) that the hostage-takers are members (chleny) of the "so-called 'Ingush Dzhamaat" with strong ties to Basaev and Maskhadov. But it also includes disclaimers from both Akhmed Zakaev (who says, "it is too early to tell who these people are, what they want and who is behind them") and Maskhadov himself, as well as statements from the Ingushetian authorities, who argue that it is too soon to draw any conclusions about the nationalities of the hostage-takers.

All three demands of the hostage-takers are mentioned only once in a single bulletin. The demand for "the withdrawal of troops from Chechnya" headlines and leads the post, and is followed immediately by the demand for "the release of twentyseven boeviki, arrested as a result of the investigation into the circumstances of the attack on state institutions (ob'ekty) on the night of 21 June this year." Later comes the "statement" on a video cassette from the hostage-takers that they will negotiate with the presidents of North Ossetia and Ingushetia and with the paediatrician Leonid Roshal, who, "in 2002 went in to the hostages in the Dubrovka theatre." Caucasian Knot's spatial and temporal positioning of these three demands indicates that it considers the withdrawal of Russian troops and the release of the boeviki as the most important. The demand for the presidents and Roshal is not even considered a demand, but simply a statement from the hostage-takers regarding with whom they are willing to negotiate. The authorities think otherwise. In the same post, State Duma deputy, Mikhail Markelov, dismisses the demand for the release of prisoners as 'conjecture' (domysly). He does not confirm the receipt of the videotape, says nothing of the withdrawal of troops, but confirms that "the bandits are demanding to summon for negotiations" the two presidents and Dr Roshal. 
Of the three Russian narratives, Caucasian Knot's includes the widest range of temporary narrators selected from federal, regional, and Chechen-Ichkerian sources, other Russian media, and, uniquely of the three, eyewitnesses. In doing so, and by making no connections with other narratives, the site avoids overtly characterising any particular narrator or actor as either 'good' or 'evil.' It reports the statements and actions of officials yet also draws attention to conflicting information; it refers to the hostage-takers as boeviki and terroristy and includes the suicide bomber belts of the women, yet it also fails to jump to conclusions about their identity and clearly states their demands. The inclusion of two personal narratives not only actualises the human cost of the attack but adds further details missed by the other two news agencies. Thus, Caucasian Knot builds up a complex, multi-vocal narrative that is not, arguably, to be unexpected from the crowded, confused, and dangerous place that Beslan became that Wednesday morning, and that contrasts with the certainty of the reductionist narratives constructed by RIA-Novosti and Kavkazcenter.

\section{Translated Narratives}

This section includes an analysis of the three English narrative texts on Beslan published on 1 September 2004 by the three news agencies. I have called them 'translated narratives,' even though, as the following analyses show, not everything is translated, and neither are English texts always translations of (parts of) the Russian texts. Yet, these differences are obscured by the hyperlinks that enable readers to simply click between Russian and English homepages, creating the illusion, and nurturing the assumption (for, surely, readers have no reason to assume otherwise) that the two are 'the same.'

\subsection{RIA-Novosti}

On September 1 2004, RIA-Novosti published sixteen English articles (about 5,700 words) that mentioned the hostage-taking in Beslan. Most of these, although presented as single dispatches, are, in fact, anonymously translated amalgamations of bulletins from the Russian text. The agency's correspondent(s) at the scene and the few references to eyewitnesses remain present, as do the numerous official statements that so characterise the Russian narrative. While fewer officials are cited (14), and a smaller proportion of the actions of government personnel is included, the characterisation of a mobilized, authoritative and effective government, unquestioned by the narrator(s), is unchanged.

Of the many international responses to the crisis present in the Russian narrative, only four occur in the English. Consequently, the narrative of 'the war on terror(ism)' that emerged so clearly in the Russian narrative is barely apparent here, although traces of it can still be found. However, almost as if to compensate for this gap, connections are unmistakable in three analytical pieces posted towards the end of the day: 'Terrorism in Russia. War on an Invisible Enemy' (Pyotr Romanov), 'How can we fight terrorists?' (Viktor Litovkin), and 'Who is behind the Chechen terrorists?' (Vyacheslav Lashkul). ${ }^{26}$ Romanov, for example, describes the Beslan attack and the explosions in Moscow and on two passenger planes as "mere episodes in the protracted war between modern civilisation and a new challenge - international terror- 
ism," and Litovkin states unequivocally that "Russia is in a state of war with terrorism." Lashkul quotes at length Oleg Nechiporenko, the general director of the National Anti-Criminal and Anti-Terrorist Foundation, who, because the Islambouli Brigades, an "international extremist group...with apparent ties to al-Qaeda," claimed responsibility for the August 24 airplane crashes, declares that,

[i]n essence, this confirms what we have long been telling the world: the separatists in the Caucasus, in particular, the Chechen Republic, maintain links with international terrorists...[and] bandit groups led by Aslan Maskhadov and Shamil Basaev include foreign mercenaries who fought in Osama bin Laden's units in Afghanistan.

Conflating 'international terrorists' with 'Chechen separatists' constructs a narrative that allows the Russian government to both legitimise, and assume international support for, its military actions and policies in Chechnya. Chechen national grievances and claims for independence can be ignored, offers of negotiation and political resolution dismissed. "We are ready for dialogue with all the forces," Romanov quotes President Putin, "except for terrorists and separatists."

Thus, Russia's role as a veteran in this war on Chechen/international terror(ism) and its position on the frontline is not only included but reinforced in the English narrative text. The accounts of the three previous major hostage-takings are translated into English, with the fates of the Chechen commanders now added to the text - Basaev becomes "internationally wanted" and Raduyev "was later captured, tried and...died in prison" - thus reinforcing both the (international) extent of the terrorist threat and the competency of the Russian government in responding to it. Furthermore, in a piece found in English only, an additional ten terrorist attacks in Moscow are briefly narrated, with three of them linked explicitly to Chechnya, including the claim that "a piece of fabric resembling the flag of the Chechen republic of Ichkeria" was found at the site of the blast.

That the attack in Beslan is a manifestation of Chechen/international terror(ism) is consistently reinforced in the English narrative by the characterisation of the hostage-takers in Beslan as Chechen. Although, as in the Russian narrative, the only reported information regarding the identity of the hostage-takers is that the group is led by the Ingush 'Magas,' a Russian grammatical passive construction, with no subject at all, is translated into English so that the school is now said to have been taken hostage by "a group of Chechen militants." In his opinion piece, Lashkul could not be more convinced of the nationality of the hostage-takers, asking not who they are but, "who is behind the Chechen terrorists?" and stating unquestionably that "Chechen terrorists have committed another crime, this time in the North Ossetian town of Beslan."

The weighting of the hostage-takers' demands found in the Russian narrative is also in the English version. Again, little is made of the presidents, while "renowned paediatrician" Dr Roshal is characterised as even more heroic. His role in the Dubrovka hostage crisis is described in glowing terms, using language (in italics in the example below) that is both noticeably different from the corresponding description in the Russian text (see 3.1 above), and almost depicts "[t]he selfless physician" as a compassionate Christ-like figure:

Leonid Roshal appeared in the tragic limelight when he volunteered to negotiate in the Dubrovka theatre plight in Moscow as terrorists took a full house hostage during a 
sensational musical in autumn 2002. At the risk of his own life, he was attending to the sick and interceded for the captives.

Like its configuration in the Russian narrative, the second demand of the hostagetakers is twice reported in terms of demanding the release of convicted terrorists before later being clarified by Aslakhanov as the release of "captured militants who were taking part in a violent attack on Ingush police premises." These prisoners are more violent in English, which adds that "one hundred people, mostly policemen, were killed...during the June attack," the implication being that the demand to release such dangerous murderers would be impossible to meet. The third demand, "that Russian forces be withdrawn from Chechnya," is reported twice, the second time as the vague, agent-less demand "to stop Chechen warfare," and no more is said about it.

Overall, the distinguishing characteristics of RIA-Novosti's Russian narrative can also be found in the English narrative. Furthermore, there is evidence to suggest that lexical choices, editorial changes and the selection of additional material are all made to reinforce particular aspects of this narrative - Russia's veteran status and Chechens as the undisputed enemy - for foreign audiences.

\subsection{Kavkazcenter and Caucasian Knot}

Nothing on Beslan in English appears on Kavkazcenter.com until the early hours of 2 September 2004 when an article of about 650 words is posted, only the first half of which covers the hostage-taking in Beslan, while the other half is devoted to the explosion on 31 August outside "the Rizhsky (sic) station in central Moscow." This is not a translation of Kavkazcenter material, but a single piece attributed to "IslamOnline. net and News Agencies," with foreign and Russian media, and various regional and federal officials quoted within the text. While this is similar to the way Kavkazcenter's Russian narrative draws not from the agency's own correspondent but on other media for information, who, in turn, draw on information from official statements, the English story has none of the caustic scepticism and criticism that so characterises the Russian.

The piece ends with four very brief paragraphs on "the small mountainous republic of Chechnya [which] has been ravaged by conflict since 1994, with just three years of relative peace," reporting a high civilian death toll and the concern of international human rights groups over abuses committed by Russian troops. Thus, just as in the Russian narrative, both the Beslan attack and the explosion at Rizhskaya are connected to the larger narrative of Chechen suffering and Russian aggression in Chechnya.

The storming of the Dubrovka theatre, however, is not mentioned. While the hostage-takers' threat to blow up the building if it is stormed by police is included, without the other poignant, critical references to the Dubrovka storm, the element only exemplifies the aggression of the hostage-takers - a characteristic underplayed by Kavkazcenter in Russian - and fails to emphasise the onus of Russian security forces to act responsibly which is such a key aspect of Kavkazcenter's Russian story.

There is no speculation at all regarding the identity of the hostage-takers. While the relatively neutral language used in the Russian story is also found here - they are "armed attackers," "kidnappers," "gunmen" and "hostage takers" - the women are described as "wearing belts laden with explosives" and "wearing explosive belts," 
characterisations missing entirely from the Russian. Neither is there any mention of the demands of the hostage-takers, which were so central to the Russian story. In spite of the connection made to Russia's wars in Chechnya, Kavkazcenter's alternative narrative, shifting focus away from the hostage-takers and onto the past, and potential, violence of the Russian government, is lost.

On 1 September 2004, Caucasian Knot posted one brief article (164 words) on the hostage-taking in Beslan, an amalgamation of anonymously translated excerpts taken from five of the Caucasian Knot Russian bulletins published that day. The brevity of the English narrative means, of course, that, as in the case of Kavkazcenter, much of the Russian narrative is simply missing; none of the elements that make Caucasian Knot's Russian narrative distinctive, neither the varied sources of information, the regional focus, nor the personal narratives, are found here.

At first glance, the English narrative appears, like the Russian, to remain circumspect regarding the identity of the "terrorists," including both the suggestion that the attack was planned in Chechnya by Basaev and Maskhadov, and the claim that the group is "under command of that very man who led the attack on Ingushetia on the night of June 21-22." However, by using the word rebel to describe first Basaev and Maskhadov, then the group that captured the school, and finally the attack on Ingushetia, the narrator conflates all three and so characterises the hostage-takers as Chechen. Similarly, while the demands of the "terrorists" are weighted in the same way as they are in the Russian narrative, in this new, pared-down version, they serve only to further characterise the hostage-takers as Chechen and, by failing to specify whose troops should be withdrawn from Chechnya, remove any Russian involvement in the situation.

\section{Conclusions}

This paper began by asking two questions: what other reporting on the Second Chechen War exists online? and, how is it communicated to non-Russian speakers, if it is at all? This case study suggests that there is indeed other reportage, with nonmainstream narrators constructing narratives that challenge and undermine official accounts by re-characterising key actors, making alternative narrative connections, and by including and re-weighting details, elements, and temporary narrators missing from official stories. Yet the English versions of these narratives are threadbare. Either the narrative is not translated at all and a brief substitute is put in its place, or only a tiny proportion of the original narrative is translated. While RIA-Novosti also translates only a part of its Russian narrative, the characteristics of that narrative remain intact, indeed, are reinforced in translation. In the case of alternative narratives, the distinguishing characteristics - that which makes them alternative - are either greatly weakened, or entirely absent, in translation.

Moreover, it seems that what makes it through the narrow gate of translation are more likely to be "the recurring and stereotypical narrative accounts" as Bennett and Edelman express it, that "can elicit powerful responses of belief or disbelief in distant audiences without bringing these audiences any closer to practical solutions that occasioned the stories in the first place" (1985: 156). RIA-Novosti, in both Russian and English, appears unable and unwilling to narrate the Beslan hostage-taking as anything but part of 'the international war on terror(ism)' manifested on Russian 
soil by the attacks of Chechen terrorists. Kavkazcenter's critical comments and recharacterisations challenge this dominant narrative, yet they are missing from the site's English narrative. What remains for the foreign reader is the narrator's insistence that the hostage-taking can only be narrated as a reaction to brutal Russian military aggression and abuses in Chechnya, leaving something of a blind spot with regard to the aggression of the hostage-takers, and suggesting an unwillingness to engage with the paradox at the heart of this narrative: that it can champion the cause but not the actions of the hostage-takers.

Narratives have the power either to ossify people's beliefs or disbeliefs, fixing them into intractable positions of conflict, or to "yield new insights, identify new points of struggle and consensus, and lead to new actions" (Bennett and Edelman 1985: 158). Of the six narratives investigated in this paper, Caucasian Knot's Russian narrative, both critical and circumspect, focused on local, particular elements, and reluctant to too quickly connect the local with larger narratives, appears to be the one more likely to lead to the second effect. In translation, however, these characteristics are missing. The goal of reaching "the world community" with multi-vocal, dissident narratives is not met here. Reasons why not, and how that might be changed, remain to be explored.

\section{NOTES}

* Thanks to Julie Boéri for this translation.

1. Chechnya featured on the humanitarian aid organisation Médecins sans Frontières / Doctors without Borders' list of 'Top Ten Underreported Humanitarian Stories' every year from 2000 to 2007. Continuing political violence, restrictive Russian legislation, and strict government control over foreign and local journalists are all contributing factors, as is the complicated and protracted nature of the conflict which largely appears confusing and irrelevant to Western audiences, especially when many countries have their own theatres of war elsewhere.

2. Many of these have come and gone over the years of the conflict. Some of the more established sites include Waynnakh Online <http://www.waynakh.com>, Daymohk Information Agency <http:// www.daymohk.info/rus/index_ie.shtml $>$, the Information Centre for the Council of Non-governmental Organisations $(\mathrm{SNO})<\mathrm{http}: / /$ www.livechechnya.org $>$, PragueWatchdog <http://www.watchdog.cz $>$, Caucasus Times <http://www.caucasustimes.com> and the Institute of War and Peace Reporting $<$ http://iwpr.net>. All sites visited on 18 January 2010. The award-winning Russian-Chechen Friendship Society was closed down by the Russian government in October 2006.

3. Except, of course, those run by the Russian government, such as Kavkazstrana.ru, Chechnyafree. $\mathrm{ru}$, and Chechnya.gov.ru.

4. See, for example, 'O Nas,' Kavkazcenter <http://www.kavkazcenter.com/russ/about> and 'O Nas,' Kavkazskii Uzel [Caucasian Knot], <http://www.kavkaz-uzel.ru/articles/AboutCaucasianKnot>, both visited on 18 January 2010.

5. 'About us,' Information Centre for the Council of Non-governmental Organisations (SNO) <http:// www.livechechnya.org/o\%20nas-ing.htm>, visited on 18 January 2010.

6. 'About us,' Prague Watchdog <http://www.watchdog.cz/index.php?show=000000-000010-000005\& lang=1>, visited on 18 January 2010.

7. In June 2007, relatives of those who died in the siege filed a lawsuit against the Russian Government in the European Court of Human Rights, claiming they have been denied the right to an objective investigation.

8. See Bruner on 'hermeneutic composability' and 'referentiality' (1991: 7-8, 13-14).

9. See, for example, Ricœur on temporality (1979), Bruner on particularity (1991) and Baker on historicity and framing (2006).

10. In an indication of the significant international attention the attack attracted, on the first day of the crisis, statements came from Georgia, Poland, Europe, Ukraine, the Cherkassian Diaspora in Syria, France, Great Britain, Chechnya, Belgium, Cyprus, NATO, India, Canada, Greece, Italy, the 
USA, the Commonwealth of Independent States (CIS), Malaysia, Germany, Belarus, the UN, Russian and international Islamic organisations, and the Russian Orthodox Church.

11. Bor'ba can also be translated as struggle or battle. It was very much a part of Soviet rhetoric that couched most of public and political life as the 'struggle' against various external and internal enemies, and the 'struggle' to build socialism, fulfil the Five-Year Plan, or bring in the harvest, for example. As such, it can sound very banal to Russians and lacks the dramatic rhetoric of 'war on terror,' although arguably this too, comparable with 'wars on' drugs or poverty, for example, has the touch of the banal about it also. All translations, unless specified otherwise, are my own.

12. This term is adopted from Glover (2002: 208), who uses it to reflect the various and non-standardized usages of both the 'war on terrorism' and the 'war on terror' found in media and political rhetoric.

13. See Baker (2006) and Harding (2009) for discussions of the 'war on terrorism' as a meta-narrative.

14. On 24 August 2004, two passenger jets flying from Moscow to Volgograd and Sochi exploded en route. On 31 August, a bomb exploded outside the Rizhskaya metro station in Moscow, killing at least ten people and wounding over fifty.

15. The usage and translation of this word is problematic (see Tishkov 2004: 90-91; Harding 2009). Nick Paton Walsh, a journalist for the Guardian, calls it "a catch-all word that epitomises the gulf in perceptions in the [Chechen] conflict. It translates directly as 'fighter,' but means to some locals 'separatist fighter' and to Russian officials 'terrorist militant'” and is thus emblematic of the contestation between circulating narratives. (30 September 2004: Tracing a Tragedy. The Guardian $<$ http://www.guardian.co.uk/world/2004/sep/30/russia.chechnya>, visited on 18 January 2010.

16. A derogatory term associated with criminals and mafia but also used, since the First Chechen War (1994-1996), for Chechen fighters. Article 209 of the Russian Criminal Code establishes 'banditry' (banditizm), involvement in a "stable armed group" (band), as a criminal offence.

17. The root of the word, smert,' means death and it is also used for males.

18. The use and translation of the words shahid and martyr are extremely problematic, partly due to their ambiguous definitions. While both Arabic and English are etymologically derived from the Greek word meaning witness, suggesting conditions of principled innocence and non-violence on the part of the martyr, the word also refers to those who use violence, such as those who die for the sake of their country during wartime and, in some Arabic narratives, those who undertake 'martyrdom operations.'

19. In June 2004, heavily armed guerrilla fighters launched attacks on several key targets in Ingushetia. Scores of people were killed and over a hundred wounded (Dunlop 2006: 24-25).

20. 'O nas,' Kavkazcenter, <http://www.kavkazcenter.com/russ/about>, visited on 18 January 2010.

21. Dmitry Shlapentokн (2006) 'The War in Chechnya and the Russian Public,' Prague Watchdog, 25 October 2006 <http://www.watchdog.cz/?show=000000-000004-000002-000027\&lang=1>, visited on 18 January 2010.

22. The placing of children in the windows is also briefly reported by RIA-Novosti, the only time it mentions a storm on September 12004.

23. This note is also reported by RIA-Novosti, but the demand to withdraw troops is not mentioned in connection with it.

24. 'O Nas,' Caucasian Knot, <http://www.kavkaz-uzel.ru/articles/AboutCaucasianKnot>, visited on 18 January 2010.

25. See Dunlop (2006: 21-29) who quotes Meteleva's (2005) direct reference to this policeman.

26. These three articles, all written by RIA-Novosti staff writers, are assumed to be translations, even though the Russian-language versions are unavailable from the RIA-Novosti archives. The lack of clear relations between texts traditionally thought of as 'source' and 'target' are another feature of online publication, an area that has, so far, received little attention.

\section{REFERENCES}

BAKer, Mona (2006): Translation and Conflict: A narrative account. London: Routledge.

BAL, Mieke (1985/1997): Narratology: Introduction to the Theory of Narrative. Toronto, Buffalo, London: University of Toronto Press.

Bell, Alan (1991): The Language of News Media. Oxford: Blackwell.

Bennett, W. Lance and Edelman, Murray (1985): Toward a New Political Narrative. Journal of Communication. 35(4):156-171. 
Bhatia, Michael V. (2005): Fighting Words: Naming terrorists, bandits, rebels and other violent actors. Third World Quarterly. 26(1):5-22.

Blandy, Charles (2004): Chechnya After Beslan. Camberley, Surrey: Conflict Studies Research Centre.

BRUner, Jerome (1991): The Narrative Construction of Reality. Critical Inquiry. 18(1):1-21.

ButLer, Judith (2004): Precarious Life: The powers of mourning and violence. London: Verso.

CARr, David (1986): Narrative and the Real World. History and Theory. 25(2):117-131.

Dolnik, Adam (2007): Negotiating the Impossible? The Beslan Hostage Crisis. London: Royal United Service Institute for Defence Studies.

Dunlop, John B. (2006): The 2002 Dubrovka and 2004 Beslan Hostage Crises. Stuttgart: ibidemVerlag.

Dzutsev, Khasan Vladimirovich (2008): Beslan posle 1-3 sentiabria 2004 goda: sotsiologocheskii analiz. Moscow: ROSSPEN.

Fisher, Walter R. (1985): The Narrative Paradigm: In the Beginning. Journal of Communication. 35(4):74-89.

Fisher, Walter R. (1987/1989): Human Communication as Narration: Toward a Philosophy of Reason, Value and Action. Columbia: University of South Carolina Press.

Fisher, Walter R. (1997): Narration, Reason and Community. In: Lewis P. Hinchman and Sandra K. Hinchman, eds. Memory, Identity, Community: The Idea of Narrative in the Human Sciences. Albany: State University of New York Press, 307-327.

Genette, Gérard (1972/1980): Narrative Discourse: An Essay on Method. (Translated by Jane E. LEwIN) Oxford: Basil Blackwell.

Glover, Ross (2002): The War on ________. In: Ross Glover and John Collins, eds. Collateral Language: A User's Guide to America's New War. New York and London: New York University Press, 207-222.

Haraszti, Miklós (2004): Report on Russian Media Coverage of the Beslan Tragedy: Access to information and journalists' working conditions. Organization for Security and Cooperation in Europe. Visited 16 January 2010, <http://www.osce.org/documents/rfm/ 2004/09/3586_en.pdf> (and also in Russian, <http://www.osce.org/documents/rfm/2004/ 09/3586_ru.pdf $>$ ).

Harding, Sue-Ann (2009): News as Narrative: Reporting and Translating the 2004 Beslan Hostage Disaster. Unpublished doctoral thesis. Manchester: University of Manchester.

Hutchings, Stephen (2009): Russia's 9/11: Abjection, Performative Identity and Television Coverage of the Beslan Atrocity. In: Stephen Hutchings and Natalia Rulyova, eds. Television and Culture in Putin's Russia: Remote Control. London: Routledge, 74-88.

Lynch, Dov (2005): The Enemy is at the Gate: Russia after Beslan. International Affairs. 81(1):141161.

MacIntyre, Alasdair (1981): After Virtue: A Study in Moral Theory. Notre Dame: University of Notre Dame Press.

Meteleva, Svetlana (2005): Otmorozhennyi Magas: Boevikov v Ingushetii ne otlichat' ot sotrudnikov MVD. Moskovskii Komsomolets 14.04.2005. Visited 08 November 2006, $<\mathrm{http}: / / \mathrm{mk} . \mathrm{ru} /$ newshop/bask.asp?artid=106104>.

Phillips, Timothy (2007): Beslan: The Tragedy of School No. 1. London: Granta Books.

Plater-Zy berk, Henry (2004): Beslan - Lessons Learned? Camberley, Surrey: Conflict Studies Research Centre.

Politkovskaya, Anna (2007): A Russian Diary. (Translated by Arch Tait) London: Harvill Secker.

Polkinghorne, Donald E. (1988): Narrative Knowing and the Human Sciences. NewYork: State University of New York Press.

PRINCE, Gerald (1987/2003): A Dictionary of Narratology. Lincoln: University of Nebraska Press. Ricceur, Paul (1979): The Human Experience of Time and Narrative. Research in Phenomenology. 9:17-34.

Rimmon-Kenan, Shlomith (1983): Narrative Fiction: Contemporary Poetics. London: Methuen. 
Russell, John (2007): Chechnya - Russia's 'War on Terror.' London and New York: Routledge. Ryan, Marie-Laure (1993): Narrative in Real Time: Chronicle, Mimesis and Plot in the Baseball Broadcast. Narrative. 1(2):138-155.

Smith, Mark A. (2004): Beslan: The Political Fallout. Camberley, Surrey: Conflict Studies Research Centre.

Snetkov, Aglaya (2007): The Image of the Terrorist Threat in the Official Russian Press: the Moscow theatre crisis (2002) and the Beslan hostage crisis (2004). Europe-Asia Studies. 59(8):1349-1365.

Somers, Margaret (1997): Deconstructing and Reconstructing Class Formation Theory: Narrativity, Relational Analysis, and Social Theory. In: John R. HALL, ed. Reworking Class. Ithaca and London: Cornell University Press, 73-105.

Somers, Margaret R. and Gibson, Gloria D. (1994): Reclaiming the Epistemological "Other": Narrative and the Social Constitution of Identity. In: Craig CALHOun, ed. Social Theory and the Politics of Identity. Oxford and Cambridge: Blackwell, 37-99.

Stepanova, Ekaterina (2004): From Dubrovka to Beslan: Who is learning faster? PONARS (Programme on New Approaches to Research and Security) Policy Memo 347. Eurasian Strategy Project: Georgetown University. Visited 16 January 2010, <https://gushare.georgetown.edu/eurasianstrategy/Memos/2004/pm_0347.pdf>.

TAYLOR, Charles (1989): Sources of the Self: The Making of the Modern Identity. Cambridge: Cambridge University Press.

Tisнкоv, Valery (2004): Chechnya: Life in a War-Torn Society. Berkeley: University of California Press.

Whiтеввоок, Maureen (2001): Identity, Narrative and Politics. London and New York: Routledge. 